\title{
OPTIMALISASI KINERJA MANAJEMEN FORUM KERUKUNAN UMAT BERAGAMA (FKUB) DALAM MENYELESAIKAN KONFLIK DAN MEWUJUDKAN KERUKUNANAN UMAT BERAGAMA DI KOTA TANGERANG SELATAN
}

\author{
Slamet Suwanto ${ }^{1}$, Ngadisah $^{2}$, Nurliah Nurdin $^{3}$, Andi Pitono ${ }^{4}$ \\ ${ }_{1,2,3,4}$ Institut Pemerintahan Dalam Negeri (IPDN) \\ Email: slammas78@gmail.com
}

\begin{abstract}
Abstrak
Penelitian ini bertujuan untuk mengungkap mencari metode yang ideal untuk optimalisasi manajemen kinerja Forum Kerukunan Umat Beragama (FKUB) Tangerang Selatan dalam upaya menyelesaikan konflik dan mewujudkan kerukunan antar umat beragama di Kota Tangerang Selatan. Penelitian ini bersifat kualitatif dengan pendekatan deskriptif. Teknik purposive digunakan dalam penentuan subjek penelitian. Hasil penelitian ini menunjukkan bahwa FKUB Tangsel belum melaksanakan manajemen kinerja organisasi sehingga peran dan kinerjanya dimasyarakat Tangerang Selatan belum maksimal dan optimal. Kehadirannya belum banyak diketahui dan manfaatnya belum banyak dirasakan masyarakat. Oleh karenanya peneliti menciptakan model TRAS-ESILINER sebagai langkah-langkah optimalisasi manajemen kinerja yang harus dilakukan.
\end{abstract}

Kata Kunci: FKUB, Manajemen Kinerja, TRAS-SILINER.

\section{Abstract}

This study aims to reveal the search for the ideal method for optimizing the performance management of the South Tangerang Religious Harmony Forum (FKUB) in an effort to resolve conflicts and create inter-religious harmony in South Tangerang City. This research is qualitative with a descriptive approach. Purposive technique is used in determining the research subject. The results of this study indicate that the Tangsel FKUB has not implemented organizational management so that its role and performance in the society of South Tangerang are not optimal and optimal. Its presence is not widely known and its benefits have not been widely felt by the community. The researchers created the ESILINARY TRAS model as steps to optimize performance management that must be taken.

Keywords: FKUB, Performance Management, TRAS-SILINER.

\section{A. PENDAHULUAN}

Manusia adalah makhluk sosial yang mana akan selalu membutuhkan orang lain disekelilingnya dalam proses menjalani kehidupannya (Krueger, 1998). Bahkan lebih dari itu, manusia baru menjadi manusia setelah manusia itu bisa hidup dan berinteraksi dengan manusia yang lainnya (Taneko, 1984). Sebagai makhluk sosial, pada dasarnya manusia diasumsikan memiliki sifat dan perilaku yang rasional serta dapat bekerjasama dengan yang lainnya, sehingga dengan itu manusia bisa saling menyampaikan ide, gagasan, pemikiran, 
keinginan dan harapan khususnya dalam kehidupan masyarakat yang dipandang sebagai sebuah realitas structural (Wursig, 2010).

Menurut Jamaludin (2015), bahwa di dalam tataran yang ideal sebagaimana disebutkan di atas, manusia bisa hidup dengan suasana yang harmonis, teratur, toleran penuh kerukunan yang mana dalam literatur ilmu sosial, kerukunan sendiri diartikan dengan istilah intergrasi (lawan disintegrasi) yang berarti the creation and maintenance of diversified patterns of interactions among outonomous units (penciptaan dan pemeliharaan beragam pola interaksi di antara unit-unit yang otonom).

Disisi lain, menurut Elias Canetti dalam Rusdiana (2015), bahwa terlepas dari segala sifat luhurnya, manusia juga memiliki kodrat hewani yang tertanam jauh dalam dirinya dan kodrat hewani ini yang memungkinkan manusia lepas dari sebab ekonomi dan politis berubah dan bertindak kejam terhadap manusia yang lainnya. Karenanya, dalam setiap interaksi manusia sebagai salah satu eksistensi sosial, akan selalu ada konflik sebagai sebuah konsekwensi adanya perbedaan dalam pengetahuan, perbedaan perasaan, perbedaan kebutuhan, perbedaan keinginan, perbedaan harapan dan perbedaan keyakinan (Flynn, 2008).

Menurut Coleman (1956), konflik sosial yang masih sering terjadi dalam kehidupan manusia bahkan sampai dengan era modern saat ini, adalah konflik keagamaan. Menurut AliFauzi dkk. (2009), konflik keagamaan diartikan sebagai perseteruan menyangkut nilai, klaim dan identitas yang melibatkan isu-isu keagamaan atau isu-isu yang dibingkai dalam slogan atau ungkapan keagamaan. Konflik antar manusia yang bernuansa agama ini terjadi hampir ada di setiap penjuru dunia dan tidak terkecuali di negara kita Indonesia.

Dari banyak peristiwa konflik bernuansa agama yang terjadi di Indonesia, peristiwa konflik yang terjadi di Ambon dan Poso adalah peristiwa konflik agama yang paling besar, dilihat dari jumlah korban yang meninggal atau luka, kerugian materi yang ditimbulkan, jangkauan wilayah konflik yang luas maupun durasi waktu terjadinya konflik yang sangat lama. Konflik Ambon yang terjadi sejak 1999 mengejutkan banyak pihak baik di tingkat lokal, nasional maupun internasional (Duncan, 2005). Konflik pecah mulai dari antar etnis kemudian berkembang menjadi konflik agama Islam dan Kristen. Awalnya kepulauan ini merupakan daerah aman yang dekat dengan sistem adat budaya seperti Pela Gandong di Ambon dan adat se atorang di Maluku Utara-Maluku Kie Raha yang merupakan empat negara tradisional antara lain Bacan, Jailolo, Tidore dan Ternate, tidak lagi berfungsi sebagai kekuatan di masa itu (Safi, 2017). 
Sungguhpun demikian, konflik keagamaan di Indonesia tidak selalu muncul dengan bentuk kekerasan fisik, sebagaimana pandangan Ali-Fauzi dkk. (2009), menyebutkan bahwa: "Konflik keagamaan di Indonesia tidak selalu dengan bentuk kekerasan seperti yang terjadi di Ambon, Poso, Tolikara dll, karena banyak juga konflik keagamaan dalam bentuk yang berbeda. Seperti yang disampaikan Konflik keagamaan itu dapat mewujud dalam dua jenis aksi, yaitu (1) aksi kekerasan dan (2) aksi damai. Dalam studi ini, aksi damai dipahami sebagai "setiap tindakan yang dilakukan tanpa kekerasan dalam rangka menanggapi isu-isu keagamaan yang menjadi sumber pertikaian di masyarakat". Termasuk di dalam aksi damai adalah aksi protes (aksi menolak suatu pandangan atau kebijakan menyangkut isu yang diperselisihkan), aksi dukungan (aksi mendukung suatu pandangan atau kebijakan menyangkut isu yang diperselisihkan), maupun aksi mediasi (tindakan yang dilakukan dalam rangka mendukung upaya penyelesaian konflik yang tengah terjadi”.

Sebagaimana disebutkan di atas bahwa diantara konflik keagamaan yang tanpa kekerasan itu adalah adanya konflik yang disebabkan oleh perselisihan rumah ibadat yang terjadi di banyak tempat di Indonesia dan tidak terkecuali di Provinsi Banten. Secara khusus pula Setara Institute menyebutkan ada 9 provinsi dengan kasus pelanggaran Kebebasan Beragama Berkeyakinan (KBB) yang tertinggi setidaknya dalam lima tahun terakhir dan datanya sebagai berikut:

Tabel 1 Provinsi dengan Pelanggaran KBB Terbanyak

\begin{tabular}{|c|l|c|}
\hline No & \multicolumn{1}{|c|}{ Provinsi } & Jumlah Kasus \\
\hline 1 & Jawa Barat & 162 \\
\hline 2 & DKI Jakarta & 113 \\
\hline 3 & Jawa Timur & 98 \\
\hline 4 & Jawa Tengah & 66 \\
\hline 5 & Nangroe Aceh Darussalam & 65 \\
\hline 6 & Dl Yogyakarta & 37 \\
\hline 7 & Banten & 36 \\
\hline 8 & Sumatera Utara & 28 \\
\hline 9 & Sulawesi Selatan & 27 \\
\hline
\end{tabular}

Sumber: Data dari Setara Institute dan diolah Peneliti (2020)

Dalam kaitan dengan kehidupan antar umat beragama, seperti data yang dirilis Puslitbang Bimas Agama serta Layanan Keagamaan Badan Litbang dan Diklat Kementerian Agama, disebutkan bahwa provinsi Banten menjadi salah satu provinsi yang berada di bawah rata-rata nasional dalam Indeks Kerukunan Umat Beragama tahun 2019. Hal itu menunjukkan bahwa persoalan kerukunan antar umat beragama di Provinsi Banten perlu 
ditingkatkan dan mendapatkan perhatian serius dari Pemerintah Daerah dan termasuk pula oleh FKUB provinsi dan FKUB kota/kab se Banten.

Diantara FKUB yang belum optimal dalam menjalankan peran dan fungsinya sebagaimana dimaksud, dan ada di provinsi Banten adalah FKUB Kota Tangerang Selatan (Tangsel). Kota Tangerang Selatan sendiri adalah kota baru, yang secara resmi baru berdiri pada tanggal 26 November 2008. Dalam perkembangannya, ada 7 (tujuh) kecamatan yang ada dan masuk wilayah kota Tangsel, yaitu: Ciputat, Ciputat Timur, Pondok Aren, Pamulang, Setu, Serpong dan Serpong Utara. Menurut data BPS Provinsi Banten, jumlah penduduk Tangsel di Tahun 2018 adalah sebanyak 1.644.899 orang (BPS, 2018). Komposisi penduduknya juga sangat heterogen, multi etnik serta menganut agama yang sangat beragam dengan semua agama resmi memiliki penganut dan tempat ibadahnya di sini.

Melihat penduduk Tangsel dalam perspektif etnisnya. Ada masyarakat asli dari etnis Betawi-Sunda, etnis Jawa, Tionghoa, Batak, Flores, Madura dan lain-lain dan banyak tinggal di daerah ini. Dalam kehidupan beragamapun hampir semua agama resmi yang diakui oleh Pemerintah ada di kota ini dan memiliki rumah ibadah disini. Selain itu, sebagian besar wilayahnya adalah perumahan atau komplek elit dan menengah dan sisanya adalah perkampungan. Keragaman yang ada tersebut, disatu sisi juga memunculkan satu kekhawatiran akan terjadinya konflik sosial masyarakat, khususnya yang bernuansa agama, lebih khusus lagi yang dipicu oleh perselisihan rumah ibadah.

Tantangan potensi dan konflik pendirian rumah ibadat tersebut, menjadi pekerjaan rumah bagi FKUB Tangsel, karena secara internal organisasi ada juga persoalan manajemen kinerjanya dengan berbagai indikator seperti faktor SDM pengurus FKUB sendiri baik dilihat dalam perspektif kompetensi, apakah mereka yang terpilih menjadi anggota FKUB tersebut merupakan orang yang kompeten baik dalam pengetahuan, pemahaman maupun pengamalan agama yang dianutnya, termasuk pula bagaimana mekanisme pemilihan di internal agama tersebut, belum lagi apakah yang bersangkutan memiliki komitmen dan waktu yang memadai sehingga bisa fokus dan konsentrasi dengan tugas besar ini, karena temuan di lapangan maupun berdasar penelitian yang lain, masih banyak didapati Pengurus FKUB yang merangkap sebagai ASN.

FKUB Tangsel sampai saat ini disinyalir belum memiliki tujuan dan visi-misi yang jelas untuk mewujudkan kerukunan umat beragama, apalagi melakukan sebuah upaya serius dalam merekonstruksi pemahaman kerukunan beragama masyarakat tanpa merelativkan agama dan atau keyakinan yang dianut masyarakat. Kegagalan dalam merumuskan hal ini 
akan menyulitkan FKUB Tangsel karena tidak memiliki parameter yang jelas tentang kerukunan, toleransi antar umat beragama yang akan diimplementasikan dalam kehidupan bermasyarakat.

Persoalan-persoalan tersebut, pada akhirnya menyebabkan keberadaan FKUB Tangsel belum banyak diketahui oleh masyarakat Tangsel, hal ini bisa jadi disebabkan karena FKUB Tangsel belum memiliki kantor sendiri yang representatif, begitu pula sangat rendahnya sosialisasi yang dilakukan baik langsung dalam bentuk seminar, silaturahim kepada umat beragama maupun lewat media cetak dan online. Lebih dari itu, bahkan untuk era tekhnologi seperti saat ini, FKUB Tangsel belum memiliki website yang memungkinkan masyarakat untuk mudah mengaksesnya. Para Pengurus FKUB juga belum banyak yang tampil dalam ruang publik seperti seminar, workshop ataupun menuangkan ide, gagasan, pandangannya tentang kerukunan beragama serta mensosialisasikan program kerukunan tersebut melalui media cetak (koran lokal) atau elektronik yang ada.

Berdasarkan uraian di atas memberikan ketertarikan bagi peneliti untuk melakukan kajian tentang optimalisasi peran FKUB Kota Tangsel dalam menyelesaikan konflik dan mewujudkan kerukunan antar umat beragama dan memperkenal metode TRAS ESILINER sebagai cara-cara dalam optimalisasi manajemen kinerja yang harus dilakukan.

\section{B. METODE PENELITIAN}

Penelitian ini menggunakan desain penelitian kualitatif dengan menggunakan metode deskriptif (Creswell, 2017). Metode ini ditujukan untuk mendeskripsikan atau menggambarkan fenomena-fenomena yang ada, baik fenomena alamiah ataupun fenomena yang merupakan rekayasa manusia.Pemilihan pendekatan ini didasarkan atas pertimbangan bahwa data yang hendak dicari adalah data yang menjelaskan tentang bagaimana kehidupan kerukunan umat beragama di Kota Tangerang Selatan serta bagaimana optimalisasi kinerja Forum Kerukunan Umat Beragama (FKUB) Tangsel untuk menyelesaikan konflik serta tercipta dan terpeliharanya kerukunan umat beragama di wilayahnya dan pelaksanaan proses yang mereka lakukan sampai saat ini.

Pandangan Creswell yang peneliti pilih sebagai pendekatan dalam penelitian kualitatif ini secara umum sama dengan Bungin (2015), yang menjelaskan bahwa penelitian kualitatif lebih menekankan pada aspek proses dari pada hanya sekedar hasil dan menurutnya penelitian kualitatif memiliki medan yang alami sebagai sumber data langsung sehingga bersifat naturalistik. Pendapat ini pula tidak jauh berbeda dengan yang disampaikan Sugiyono 
(2017), dengan mengutip pendapat dari Erickson \& Stainback (2003) menjelaskan bahwa ciri penelitian kualitatif adalah bahwa penelitian ini dilakukan secara intensif, peneliti ikut berpertisipasi lama di lapangan, mencatat secara hati-hati apa yang terjadi, melakukan analisis reflektif terhadap berbagai dokumen yang ditemukan di lapangan dan membuat laporan penelitian secara mendetail.

\section{HASIL DAN PEMBAHASAN}

Berdasarkan hasil observasi peneliti ke berbagai tempat penelitian khususnya di wilayah Tangsel, maupun ke Kota Salatiga dan Kabupaten Bantul, maka peneliti berpendapat bahwa kehidupan yang rukun dan harmonis dalam perbedaan adalah keinginan dan harapan seluruh lapisan masyarakat tanpa terkecuali. Akan tetapi, mewujudkan kerukunan antar umat beragama dalam kehidupan masyarakat tersebut, bukanlah tugas yang ringan dan mudah. Oleh karena itu, Forum Kerukunan Umat Beragama (FKUB) sebagai organisasi yang mendapatkan mandat untuk menjalin hubungan baik antar umat beragama harus senantiasa melakukan upaya optimalisasi manajemen kinerjanya dalam upaya untuk melaksanakan tugas dan tanggungjawabnya sebagaimana yang diatur dalam PBM Nomor 09 dan 08 Tahun 2006.

Secara umum persoalan yang dihadapi oleh FKUB dibanyak daerah tidak jauh berbeda dengan yang dihadapi oleh FKUB Tangsel. Sebagaimana banyak diulas dalam bab sebelumnya bahwa persoalan FKUB Tangsel meliputi:

1. Minimnya bantuan pendanaan dari Pemkot Tangsel dan menjadi justifikasi bagi Pengurus untuk tidak melakukan sesuatu, padahal belajar dari FKUB Salatiga dan FKUB Bantul, mampu dan bisa melaksanakan kegiatan (sosialisasi) tanpa bergantung dengan pendanaan, khususnya dengan memanfaatkan teknologi.

2. Secara kelembagaan belum banyak diketahui oleh elemen masyarakat, karena sangat minim dan terbatasnya sosialisasi yang dilakukan.

3. Manajemen kinerja organisasi belum berjalan, tidak ada kejelasan visi kerja, tidak ada rapat rutin, kegiatan yang terencana serta evaluasi.

4. Tidak ada pelatihan bagi Pengurus untuk meningkatkan kompetensi yang dimiliki, khususnya dalam komunikasi, sosialisasi, sinergi maupun mediasi dan negosiasi.

Selain masalah internal dalam organisasi tersebut di atas, FKUB Tangsel dalam hubungannya dengan masyarakat (umat beragama) dituntut untuk mampu menganalisa penyebab perselisihan (konflik) antar umat beragama yang terjadi, umumnya tidak dipicu 
oleh persoalan dalam keyakinan agamanya, tetapi lebih banyak disebabkan oleh faktor-faktor lain yang meliputi politik, ekonomi, ketidak adilan.

Dalam masalah ekonomi, kasus perselisihan antar ormas pemuda yang menimbulkan banyak korban, adalah diantara bentuk rebutan lahan dengan motif ekonomi, belum lagi kecemburuan terhadap pendatang yang berhasil secara ekonomi juga banyak terjadi. Faktor ketidak adilan sangat terkait erat dengan kebijakan Pemerintah yang memiliki kewenangan. Akumulasi kekecewaan masyarakat terhadap kebijakan Pemerintah yang tidak memihak rakyat bisa menjadi pemicu perselisihan ataupun konflik sosial. Konflik itu terjadi ketika komunikasi antar umat beragama tidak berjalan dengan baik. Mandeknya komunikasi itu setidaknya disebabkan karena dua hal sebagai berikut:

1. Pemahaman agama yang memandang perbedaan agama sebagai musuh yang memang harus dimusuhi.

2. Perasaan saling curiga antara umat beragama. Misalnya dalam kasus terorisme, harus ada pandangan yang sama bahwa terorisme itu bukan Islam, dan bahkan tidak beragama. Adanya upaya mengaitkan terorisme dengan Islam pada akhirnya membuat umat lain curiga dengan umat Islam.

Oleh karena itu dalam penelitian ini, dalam pandangan peneliti untuk melakukan upaya optimalisasi manajemen kinerja bagi FKUB Tangsel sebagai sebuah organisasi nirlaba dengan beban tugas berat sebagaimana tertuang dalam PBM Nomor 09 dan 08 Tahun 2006 tersebut, tidak cukup hanya dengan menggunakan teori manajemen kinerja saja,lebih dari itu sangat diperlukan manajemen sosial. Hal itu karena yang dihadapi dan dikelola oleh FKUB Tangsel adalah tantangan perbedaan orang / kelompok / komunitas / umat dengan sebab perbedaan agama, apalagi Kota Tangsel ini termasuk kota yang sangat heterogen di Provinsi Banten.

Peneliti membuat sebuah model manajemen sosial sebagai sebuah upaya optimalisasi manajemen kinerja bagi Forum Kerukunan Umat Beragama (FKUB) Tangsel dan sekaligus juga menjadi sebuah model kerukunan antar umat beragama yang ideal di kota Tangerang Selatan untuk di implementasikan oleh FKUB Tangsel khususnya, dan umumnya seluruh umat beragama, ormas keagamaan, termasuk pula oleh instansi pemerintahan Kesbangpol Tangsel dan Kankemenag Tangsel.

Peneliti menyebut model ini dengan nama Model Manajemen Sosial TRASESILINER. Adapun muatan dalam manajemen sosial yang dimaksud dengan TRASESILINER tersebut meliputi: Tujuan - Rencana - Aktivitas - Evaluasi - Etika - Silaturahmi 
- Sosialisasi - Sinergi $=$ HARMONI. Dalam model ini, ada 8 (delapan) langkah yang harus dilakukan oleh FKUB Tangsel (khususnya) dan seluruh umat beragama pada umumnya, untuk mewujudkan tujuan utama terciptanya HARMONI dalam kehidupan masyarakat, sebagaimana dapat dilihat dalam gambar di bawah ini:

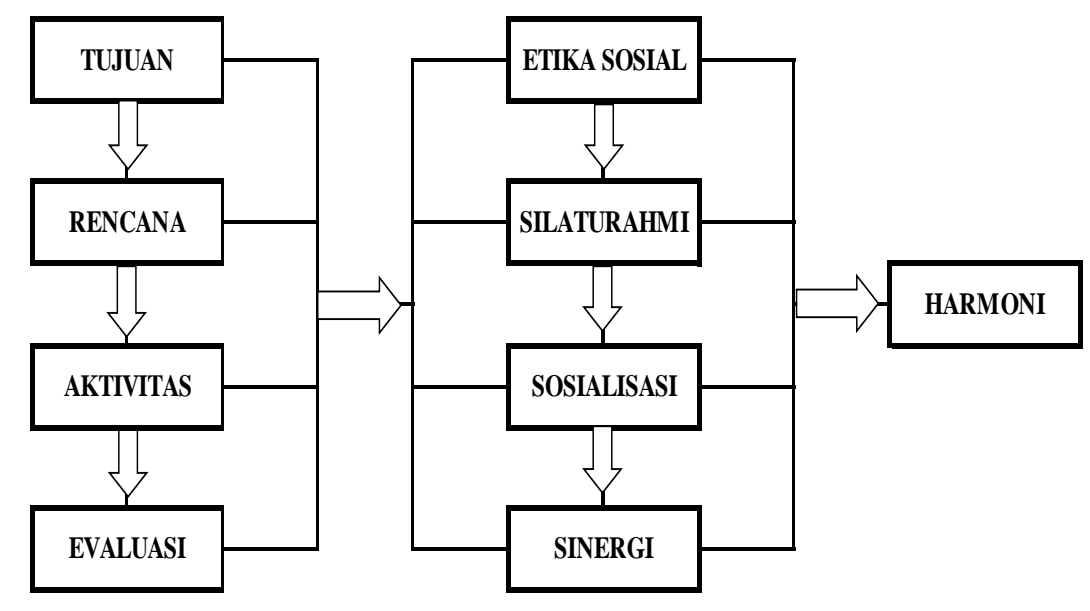

\section{Gambar 1 Model TRAS ESILINER}

Model Manajemen Sosial TRAS - ESILINER ini adalah hasil dari proses penelitian yang peneliti lakukan dalam penelitian ini dan dengan tetap menempatkan Forum Kerukunan Umat Beragama (FKUB) Tangsel sebagai pionir terdepan dalam upaya menciptakan kerukunan dan menyelesaikan konflik antar umat beragama di kota Tangerang Selatan. Dalam implementasi model ini, ada 8 (delapan) langkah yang harus dilakukan baik itu oleh organisasi FKUB Tangsel maupun seluruh umat beragama untuk mewujudkan keselarasan ataupun HARMONI dalam kehidupan masyarakat Kota Tangsel yang heterogen.

Dalam model ini peneliti membuat 8 (delapan) langkah menuju Harmoni, yangmana langkah pertama sampai dengan keempat (1-4) adalah langkah optimalisasi FKUB Tangsel sebagai sebuah organisasi dan langkah kelima sampai dengan ketujuh (5-8), harus bisa dilakukan oleh organisasi maupun seluruh komponen masyarakat (umat beragama) di kota Tangsel. Adapun langkah-langkah implementasi dan penjelasan dari Model Manajemen Sosial TRAS - ESILINER tersebut, dapat diuraikan sebagai berikut:

Pertama, Tujuan. Sebagaimana tertuang dalam PBM Nomor 09 dan 08 Tahun 2006 dinyatakan bahwa Forum Kerukunan Umat Beragama, yang selanjutnya disingkat FKUB, adalah forum yang dibentuk oleh masyarakat dan difasilitasi oleh Pemerintah dalam rangka membangun, memelihara, dan memberdayakan umat beragama untuk kerukunan dan kesejahteraan. Kerukunan umat beragama adalah keadaan hubungan sesama umat beragama yang dilandasi toleransi, saling pengertian, saling menghormati, menghargai kesetaraan 
dalam pengamalan ajaran agamanya dan kerjasama dalam kehidupan bermasyarakat, berbangsa dan bernegara di dalam Negara Kesatuan Republik Indonesia berdasarkan Pancasila dan Undang-Undang Dasar Negara Republik Indonesia Tahun 1945.

FKUB Tangsel sebagai sebuah organisasi harus memiliki rencana strategis dan dimulai dengan menyatakan tujuan yang hendak dicapai dalam periode waktu tertentu yang telah ditetapkan. Dengan kata lain bahwa tujuan FKUB Tangsel adalah merupakan sebuah proses manajemen yang memastikan seluruh Pengurus FKUB mengetahui dengan pasti peran apa yang harus dilakukan dan hasil seperti apa yang perlu mereka capai untuk memaksimalkan peran dan kontribusinya pada keseluruhan aktivitas organisasi. Oleh karena itu, dengan adanya tujuan yang jelas pula memungkinkan seluruh Pengurus FKUB Tangsel mengetahui tugas dan tanggungjawab apa yang saat ini mereka emban, kompetensi seperti apa yang diperlukan, serta bagaimana kinerja dan kontribusinya terhadap pencapaian tujuan tersebut bisa dinilai.

Kedua, Rencana yang dimaksudkan dalam hal ini adalah perencanaan yang harus dilakukan oleh FKUB Tangsel untuk perencanaan strategis organisasi dalam mengimplementasikan tujuan yang telah ditetapkan. Berdasarkan hasil penelitian dan pembahasan dalam penelitian ini, bahwa FKUB Tangsel selama ini belum melakukan perencanaan dalam kegiatan yang dilakukannya selama ini yang terstruktur dan sistemik dengan baik.

FKUB Tangsel harus membuat Rencana Kerja dan Anggaran Tahunan sebagai acuan dalam pelaksanaan kinerjanya, sehingga jelas tentang apa kegiatan yang harus dilakukan, kapan, dimana, berapa biayanya, siapa segmennya, siapa penanggungjawabnya dan sebagainya. Apabila selama ini, FKUB Tangsel berdalih dengan tidak adanya anggaran untuk melakukan kegiatan, akan tetapi faktanya belajar dari FKUB Bantul khususnya, ternyata mereka bisa melakukan beragam kegiatan dengan memanfaatkan sumberdaya pengurus termasuk memanfaatkan teknologi yang mudah dan murah.

Persoalan penting dalam perencanaan FKUB Tangsel yang juga menjadi beban adalah kegagalan organisasi ini dalam menilai sumber daya internal organisasi yang dimiliki. Sumberdaya yang dimaksud bisa meliputi SDM pengurus yang merupakan representasi umat beragama di Tangsel, dana, waktu, dan teknologi. Kesemua sumberdaya yang dimaksud tersebut belum dimanfaatkan, oleh organisasi terbukti hanya untuk bertemu dalam rapat rutin saja masih sulit untuk dilakukan. Oleh karenanya harus ada perubahan mendasar dari internal 
organisasi FKUB Tangsel ke depan, sehingga mampu melaksanakan tugasnya dengan baik dan memenuhi harapan masyarakat Tangsel dalam persoalan kehidupan beragama.

Ketiga, Aktivitas adalah implementasi atau pelaksanaan dari perencanaan strategis ke dalam langkah nyata di lapangan. Tujuan yang sangat jelas, perencanaan yang baik harus dilanjutkan dengan kerja-kerja lapangan sebagai pembuktiannya, karena aktivitas dimaksud adalah merupakan pelaksanaan dari perencanaan yang merupakan langkah program sebelumnya.Dalam pelaksanaan program ini, sebenarnya FKUB Tangsel memiliki modal berharga yaitu Sumber Daya Manusia (SDM) Pengurus yang cukup dan memadai yang berasal dari seluruh agama resmi yang ada dengan syarat dan ketentuan yang berlaku.

Dengan SDM Pengurus FKUB Tangsel tersebut mestinya pelaksanaan program kegiatan yang dilakukan oleh organisasi bisa berjalan dengan baik, akan tetapi ternyata dalam realita kepengurusan periode kedua ini (berakhir tahun 2019), pelaksanaan program FKUB Tangsel khususnya dalam Sosialisasi PBM No.09 dan 08 Tahun 2006 masih sangat jauh dari harapan masyarakat Tangsel, dengan hanya cakupan 7 kecamatan saja belum bisa melaksanakannya di seluruh kecamatan. Bandingkan dengan FKUB Bantul dengan 17 kecamatan, tetapi mereka bisa melaksanakan sosialisasi ini dengan sangat baik.

Oleh karenanya harus ada perubahan ke depan dalam perbaikan perubahan kinerja yang berkelanjutan pada dasarnya dimulai dari perubahan individu (pengurus) yang ada di dalamnya. Dengan perubahan kepada sikap dan perilaku pengurus secara personal dalam pemaksanaan tugas dan tanggungjawab di FKUB Tangsel ini maka ia akan memfokuskan diri kepada apa yang menjadi tugas saya, apa yang harus saya lakukan dan apa yang bisa saya rubah untuk kondisi yang lebih baik. Dengan kata lain menguatkan kembali bahwa perubahan dalam kinerja dan aktivitas FKUB Tangsel ditentukan oleh perubahan para individu pengurus yang ada di dalamnya, sehingga semakin baik kinerjanya maka akan berbanding lurus dengan kepuasan masyarakat (umat beragama) di kota Tangsel terhadap organisasi ini.

Keempat, Evaluasi. Dalam hal ini, evaluasi terhadap kinerja FKUB Tangsel adalah untuk memberikan penilaian terhadap hasil-hasil kerja ataupun prestasi kerja yang telah dilakukan atau diperoleh oleh organisasi, tim ataupun individu pengurusnya.

Dalam hal ini, evaluasi terhadap kinerja yang dilakukan oleh FKUB Tangsel adalah langkah yang sangat penting untuk dilakukan. Selama ini belum ada evaluasi yang memadai baik oleh Pengurus maupun instansi terkait terhadap kinerja FKUB Tangsel, sehingga ada kesan yang penting ada kepengurusannya. Padahal sejatinya evaluasi ini sangat penting bagi 
organisasi FKUB Tangsel, para pengurusnya sebagai tim maupun personal yang merupakan representasi umat beragama di kota Tangerang Selatan.

Salah satu pendekatan dalam evaluasi yang penting adalah evaluasi terhadap tujuan dan sasaran FKUB Tangsel itu sendiri. Evaluasi tujuan diperlukan untuk mengetahui apakah tujuan yang telah ditetapkan oleh organisasi bisa tercapai atau tidak, dan kemudian apabila tujuan yang telah ditetapkan tersebut tidak tercapai harus dicari faktor-faktor yang menyebabkannya. Begitu pula dengan evaluasi terhadap sasaran FKUB Tangsel, apakah sudah sesuai dengan harapan, apa kendalanya dsb. Substansi dari evaluasi ini tentu saja adalah bagaimana memberikan umpan balik bagi proses perencanaan dalam menetapkan dan melakukan tujuan dan sasaran kinerja organisasi FKUB Tangsel diwaktu yang akan datang.

Kelima, Etika Sosial. Dalam kehidupan manusia memerlukan etika dan moral dalam segala sisi kehidupan termasuk didalamnya pada kehidupan beragama, bermasyarakat berbangsa dan bernegara. Etika dan moral ini harus ada dalam kehidupan antar umat beragama, karena dengannya kita akan mengetahui dan memahami pedoman yang menjadi landasan dalam kehidupan tentang apa yang baik dan apa yang buruk, mana yang boleh dilakukan begitu juga mana yang tidak boleh dilanggar, mana kewajiban yang harus ditunaikan dan apa hak yang bisa didapatkan dlsb.

Menurut Suradinata (2013), bahwa secara umum pilar etika tersebut dapat dikelompokkan menjadi dua, yaitu etika sosial dan etika khusus. Etika sosial adalah mempelajari keterkaitan setiap individu dalam kehidupan sosial yang dapat bermakna bagi orang lain, sehingga dapat menjadi ukuran-ukuran ataupun keteladanan bagi individu yang lainnya. Aktivitas yang baik ini menjadi ukuran ataupun pedoman berperilaku dalam kehidupan sosial (kehidupan beragama, bermasyarakat, berbangsa, bernegara). Adapun etika khusus pada dasarnya masih bagian dari etika sosial, hanya saja lebih menekankan pada pembidangan karena adanya tujuan individu atau penugasan untuk tujuan tertentu.

Dalam pandangan peneliti bahwa adanya etika sosial ini sangat penting sebagai langkah optimalisasi FKUB Tangsel dalam upaya untuk menyelesaikan konflik dan menciptakan kerukunan antar umat beragama. Masuknya etika sosial dalam hal ini malah berfungsi ganda yaitu dalam perspektif FKUB Tangsel sebagai sebuah organisasi dan masyarakat (umat beragama) sebagai entitas sosial. Dalam perspektif organisasi, etika ini akan menjadi panduan bagi Pengurus FKUB Tangsel agar tidak melakukan sesuatu yang bertentangan dengan norma, misalnya rangkap jabatan Ketua FKUB Tangsel dengan 
menjabat juga menjadi Pengurus FKUB di daerah lain. Memang secara aturan tidak ada larangan, tetapi secara etika tentu saja kurang etis.

Sementara itu dalam perspektif masyarakat umat beragama di Tangsel, etika sosial ini sangat penting untuk diterapkan dalam kehidupan, hal itu karena penerapan etika sosial ini akan membuat kehidupan lebih nyaman dan menyenangkan serta bisa menjadi faktor terciptanya keharmonisan dalam pergaulan.

Keenam, Silaturahmi, sudah menjadi bahasa umum semua orang dan lintas agama. Aktifitas ini adalah kegiatan informal dengan saling berkunjung dengan sebuah pendekatan hati. Intinya adalah untuk menjalin hubungan persaudaraan, menjaga hubungan itu ataupun memperbaiki hubungan persaudaraan hubungan itu sendiri. Satu diantara banyak manfaat silaturahmi itu adalah memupuk rasa cinta kasih terhadap sesama, meningkatkan rasa kebersamaan dan kekeluargaan serta mempererat dan memperkuat tali persaudaraan dan persahabatan.

Kesadaran itu pula yang harus dilakukan oleh FKUB Tangsel dengan menjalin komunikasi dengan tokoh lintas agama di Tangsel melalui silaturahmi. Tokoh agama itu adalah representasi dan juga panutan bagi umatnya, sehingga manakala melalui silaturahmi itu komunikasi sudah terjalin, pada gilirannya akan membantu untuk melakukan langkahlangkah untuk membuat program kerukunan antar umat beragama yang membuat hubungan antar umat beragama bisa terjalin.

Hubungan yang erat yang telah terjalin pada gilirannya, membuat akan FKUB Tangsel bisa melakukan banyak program silaturahmi untuk eksternal FKUB, apakah itu tokoh lintas agama, masyarakat, atau dengan Kankemenag Tangsel dan Kesbangpol Tangsel. Hubungan baik yang telah terjalin dengan baik yang diteladankan dan selalu contohkan itu, juga akan membuat masyarakat di akar rumput tenang dalam menjalani kehidupannya. Selain manfaatnya yang besar, silaturahmi ini adalah program yang berberkelanjutan, murah dari sisi biaya, bisa dilaksanakan kapan dan dimana saja dan dalam suasana akrab apa adanya tanpa adanya rekayasa.

Silaturahmi antar umat beragama diarahkan untuk terciptanya saling pengertian dan saling menghargai diantara umat beragama. Masyarakat harus terus dilakukan edukasi untuk memahamkan bahwa semua agama mengajarkan hidup rukun penuh toleransi, serta memahami makna hidup yang rukun diantara sesame manusia, dan yang tidak kalah penting dalam silaturahmi ini adalah bagaimana peran negara hadir untuk menciptakan rasa aman maupun ketertiban dalam kehidupan antar umat beragama dengan dibentuknya Forum 
Kerukunan Antar Umat Beragama (FKUB) di seluruh provinsi dan kabupaten/kota di Indonesia.

Ketujuh, Sosialisasi ini bukanlah sesuatu yang asing bagi FKUB secara umum, karena bila merujuk kepada Peraturan Bersama Menteri Agama dan Menteri Dalam Negeri No.09 dan No.08 Tahun 2006 diantara tugas utama FKUB adalah untuk menyosialisasikan peraturan tersebut ke seluruh elemen agama dan masyarakat tanpa terkecuali, akan tetapi faktanya di lapangan banyak FKUB yang tidak bisa melakukan kegiatan sosialisasi ini (termasuk FKUB Tangsel) dengan berbagai kendala yang dihadapi. Pada hal diantara muatan penting dari PBM No. 09 dan No. 08 Tahun 2006 yang harus disosialisasikan adalah tentang pendirian rumah ibadat, yang mana persoalan ini berpotensi menjadi pemicu utama konflik antar umat beragama di kota Tangerang Selatan.

Dalam kegiatan sosialisasi, baik yang dilakukan oleh FKUB Tangsel, ataupun para pemuka agama di Tangsel, selain upaya untuk menyampaikan PBM di atas, namun sejatinya adalah upaya dan langkah yang tepat dalam menjaring aspirasi yang disampaikan oleh umat beragama di akar rumput. Dengan demikian ada kesempatan kita untuk bisa mendengar kebutuhan, keinginan maupun persoalan antar umat beragama, sehingga forum sosialisasi diisi dengan asupan informasi yang mendidik dan mencerahkan.

Seluruh anggota FKUB Tangsel harus banyak melakukan silaturahmi dan sosialisasi kepada masyarakat sehingga bisa mendengarkan dengan baik setiap keluhan dan permasalahan kerukunan umat beragama di Tangerang Selatan. Hanya saja, silaturahmi yang dilakukan saat ini baru pada tataran atas apakah itu para pemuka agama, dan para pejabat pada dinas terkait apakah kepada Kesbangpol Tangsel ataupun Kankemenag Tangsel belum menyentuh kepada masyarakat bawah. Demikian pula sosialisasi PMB yang dilakukan juga belum berjalan dengan maksimal dan optimal. Program yang sudah berjalan dengan baik, harus dijaga dan tingkatkan lagi sehingga hasilnya akan lebih baik dan maksimal.

Kedelapan, Sinergi yang muatannya adalah supaya antar umat beragama ada kesadaran untuk saling bekerjasama dan saling membantu. Kerjasama, yakni aspek hubungan sosial antara para pemeluk agama yang berbeda dalam berbagai sisi kehidupan sosial, pendidikan, ekonomi, kemanusiaan dan kebangsaan. Contoh nyata dari kerjasama ini adalah bagaimana antar umat beragama melakukan upaya untuk ikut berperan aktif melawan narkoba, dan ikut melakukan tindakan preventif dari perilaku-perilaku negatif masyarakat (khususnya generasi muda) di Kota Tangsel seperti tawuran pelajar, miras, kriminalitas serta tindakan asusila di tengah masyarakat. Sementara itu saling membantu adalah buah dari 
kesadaran bahwa sebagai makhluk sosial, kita akan tetap memerlukan bantuan orang lain dalam kehidupan kita. Saling membantu dalam kehidupan sosial kemasyarakatan harus senantiasa ditumbuhkan serta terus dilakukan tanpa melihat dan membedakan keyakinan yang dianut, seperti: kerja bakti lingkungan, ronda untuk keamanan, gotong royong, menjenguk yang sakit, menolong yang kesusahan, menjaga keamanan dan ketertiban dlsb.

Selain itu, sinergi adalah bentuk upaya untuk memadukan kekuatan, kebersamaan, keunggulan dalam dan untuk kebermanfaatan. Dalam hal ini umat beragama harus diarahkan untuk mencari titik temu diantara perbedaan keyakinan (agama) yang dianut oleh masyarakat Tangsel dan titik temu itu adalah nilai-nilai kemanusiaan, kebangsaan dalam bingkai Negara Kesatuan Republik Indonesia tercinta. Indonesia yang lahir dan merdeka dengan tetesan darah dan nyawa para pahlawan bangsa itu, mesti dijaga keutuhannya, dengan meningkatkan persatuan dan kesatuan seluruh komponen bangsa.

Oleh karenanya sinergi lintas agama itu bukan untuk menyatukan aqidah (keyakinan) yang berbeda, tetapi melakukan daya dan upaya bersama menciptakan kerukunan dalam kehidupan serta secara aktif melakukan pembinaan, pendampingan, pengarahan khususnya kepada generasi muda penerus bangsa. Para pemuka agama harus senantiasa menjelaskan bahwa ditaqdirkannya kita semua untuk tinggal di Tangerang Selatan ini bukanlah tanpa maksud. Semuanya ada arti dan maknanya dan itu adalah bahwa Tuhan telah mengutus kita semuanya, tanpa memandang berasal dari suku apa, pekerjaannya apa, agama nya apa untuk secara aktif dan bersama-sama membangun Kota Tangerang Selatan.

Kedelapan langkah dalam Model Manajemen Sosial TRAS - ESILINER sebagaimana diuraikan di atas, merupakan langkah optimalisasi manajemen kinerja dari FKUB Tangsel yang memperbaiki secara organisasi, sebagaimana yang disebutkan dalam langkah pertama sampai dengan keempat yaitu (Tujuan - Rencana - Aktivitas - Evaluasi). Sementara itu, langkah kelima sampai dengan kedelapan yaitu (Etika Sosial - Silaturahmi - Sosialisasi Sinergi) adalah model interaksi sosial antar umat beragama yang ideal untuk diimplementasikan, bukan hanya oleh FKUB Tangsel sebagai sebuah organisasi, akan tetapi lebih dari itu bisa dilakukan seluruh komponen masyarakat (umat beragama).

Tujuan akhir dari Model Manajemen Sosial TRAS-ESILINER tersebut adalah terciptanya HARMONI ataupun keselarasan dalam kehidupan antar umat beragama di kota Tangerang Selatan. Harmoni tersebut memiliki muatan utama yaitu adanya saling pengertian dan saling membutuhkan sehingga antar umat beragama ada kesadaran untuk saling bekerjasama dan saling membantu. Kerjasama, yakni aspek hubungan sosial antara para 
pemeluk agama yang berbeda dalam berbagai sisi kehidupan sosial, pendidikan, ekonomi, kemanusiaan dan kebangsaan. Contoh nyata dari kerjasama ini adalah bagaimana antar umat beragama melakukan upaya untuk ikut berperan aktif melawan narkoba, dan ikut melakukan tindakan preventif dari perilaku-perilaku negatif masyarakat (khususnya generasi muda) di Kota Tangsel seperti tawuran pelajar, miras, kriminalitas serta tindakan asusila. Sementara itu saling membantu adalah buah dari kesadaran bahwa sebagai makhluk sosial, kita akan tetap memerlukan bantuan orang lain dalam kehidupan kita. Saling membantu dalam kehidupan sosial kemasyarakatan harus senantiasa ditumbuhkan serta terus dilakukan tanpa melihat dan membedakan keyakinan yang dianut, seperti: kerja bakti lingkungan, ronda untuk keamanan, gotong royong, menjenguk yang sakit, menolong yang kesusahan, menjaga keamanan dan ketertiban dlsb.

Oleh karena itu, banyak pekerjaan rumah yang harus dilakukan oleh FKUB Tangsel maupun para pemuka agama di Tangsel dan seluruh masyarakat (umat beragama) di Tangsel, diantaranya adalah bahwa ke depan acara atau kegiatan yang dilakukan untuk menciptakan kerukunan antar umat beragama, bukan hanya dalam bentuk acara-acara seremonial saja, tetapi yang lebih penting menyentuh langsung ke permasalahan umat beragama yang sejatinya juga merupakan permasalahan yang dihadapi oleh Pemkot Tangsel itu sendiri. Perlu dipahami bahwa langkah kelima sampai dengan kedelapan yaitu kegiatan Etika Sosial, Silaturahmi, Sosialisasi, Sinergi (ESILINER) adalah langkah-langkah yang bisa dilakukan oleh seluruh komponen masyarakat (umat beragama) di Kota Tangsel tanpa terkecuali.

\section{KESIMPULAN}

Dalam rangka untuk melakukan optimalisasi FKUB Tangsel sebagai sebuah organisasi nirlaba yang mengelola perbedaan dalam keyakinan (agama) dalam masyarakat yang sangat heterogen, tidak cukup dengan menggunakan teori manajemen kinerja saja, akan tetapi sangat diperlukan manajemen sosialOptimalisasi manajemen kinerja FKUB Tangsel serta untuk menyelesaikan konflik dan menciptakan kerukunan antar umat beragama yang ideal di Kota Tangsel memerlukan delapan langkah sebagai model ideal yang harus dilakukan, yang mana model manajemen sosial tersebut diberi nama TRAS ESILINER. Kedelapan langkah dalam model manajemen sosial TRAS ESILINER tersebut merupakan langkah optimalisasi manajemen kinerja dari FKUB Tangsel yang memperbaiki secara organisasi, sebagaimana yang disebutkan dalam langkah pertama sampai dengan keempat yaitu (Tujuan - Rencana - Aktivitas - Evaluasi). Sementara itu, langkah kelima sampai 
dengan kedelapan yaitu (Etika - Silaturahmi - Sosialisasi - Sinergi) bisa dilakukan oleh seluruh komponen masyarakat (umat beragama) di Kota Tangsel. Indikator sederhana dari Etika dimaksud adalah kesopanan dan keramahan tentu saja dalam berucap dan bertindak. Sementara indikator dari Silaturahmi adalah adanya sikap saling pengertian dan saling menghargai antar umat beragama, selanjutnya muatan dari Sosialisasi adalah mendidik dan mencerahkan umat beragama, dan terakhir muatan dari Sinergi adalah saling bekerjasama dan saling membantu dalam kehidupan antar umat beragama di kota Tangsel. Apabila delapan langkah ini diterapkan secara konsisten oleh FKUB Tangsel dan seluruh umat beragama yang ada di kota ini, maka akan tercipta HARMONI, yaitu keselarasan dalam kehidupan sosial masyarakat yang tetap rukun dan harmonis walaupun dalam perbedaan.

\section{DAFTAR PUSTAKA}

Ali-Fauzi, I., Alam, R. H., \& Panggabean, S. R. (2009). Pola-pola Konflik Keagamaan di Indonesia (1990-2008). Jakarta: Paramadina-MPRK UGM-The Asia Foundation.

BPS Provinsi Banten. (2018). Banten Dalam Angka 2018. Banten: BPS.

Bungin, H. (2015). Penelitian Kualitatif. Jakarta: Kencana Prenada Media Group.

Coleman, J. S. (1956). Social cleavage and religious conflict. Journal of Social Issues.

Creswell, J.W. (2017). Research Design. Yogyakarta: Pustaka Pelajar.

Duncan, C. R. (2005). The other Maluku: Chronologies of Conflict in North Maluku. Indonesia, (80), 53-80.

Fadhli, R. (2013). Manajemen Organisasi. Bandung: Cipta Pustaka Media Perintis.

Flynn, C. P. (2008). Social Creatures: A Human and Animal Studies Reader. Lantern Books.

Jamaludin, A. N. (2015). Agama \& Konflik Sosial: Studi Kerukunan Umat Beragama. Bandung: Pustaka Setia.

Krueger, J. (1998). On the perception of social consensus. In Advances in Experimental Social Psychology (Vol. 30, pp. 163-240). Academic Press.

Robbins, S. (2018). Perilaku Organisasi. Jakarta: Salemba Empat.

Rusdiana, H. A. (2015). Manajemen Konflik. Bandung: Pustaka Setia.

Safi, J. (2017). Konflik Komunal: Maluku 1999-2000. ISTORIA: Jurnal Pendidikan dan Sejarah, 13(1).

Sugiyono. (2017). Metode Penelitian Kualitatif. Bandung: Alfabeta.

Suradinata, E. (2013). Analisis Kepemimpinan Strategi Pengambilan Keputusan. Sumedang: Alqaprint.

Taneko, S. (1984).Sruktur dan Proses Sosial. Jakarta: Rajawali.

Würsig, B. (2010). Social creatures in a changing sea: Concluding remarks. In The Dusky Dolphin (pp. 355-357). Academic Press. 